\title{
抽出脱脂法のセラミックス射出成形体への応用
}

\author{
斎 藤 勝 義认1, 寒 川 喜 光山1 \\ 飴山惠江，金子泰 成放
}

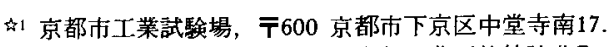

的 2 立命館大学理工学部, $\mathbf{T} 603$ 京都市北区等持院北町.

\section{Application of Binder Extraction to Ceramics Injection Molding Parts}

\author{
Katsuyoshi Saitoh ${ }^{\natural 1}$, Yoshimitsu Kankawa ${ }^{\text {1 } 1}$ \\ Kei Ameyama ${ }^{\natural 2}$ and Yasunari Kaneko ${ }^{\text {«2 }}$
}

it Kyoto Municipal Institute of Industrial Research, 17 Chudouji-minamimachi Simogyo-ku Kyoto 600 .

$\$^{2}$ Faculty of Science and Engineering, Ritsumeikan University, Tojiin-kitamachi Kita-ku Kyoto 603.

Received December 27, 1990

\begin{abstract}
A testing of ceramics injection molding of alumina powder using a PE (polyethlene)-PP (polypropyrene)peanut oil binder system was carried out. When the green parts were immersed in an acetone solvent at $23^{\circ} \mathrm{C}$ for $6 \mathrm{hr}$, the $78 \%$ of peanut oil was extracted. The residual parts were debound in air at $420^{\circ} \mathrm{C}$ for $2 \mathrm{hr}$. The heating rate was $2.5^{\circ} \mathrm{C} / \mathrm{min}$ in the temperature range from room temperature to $50^{\circ} \mathrm{C}$, and $100^{\circ} \mathrm{C} / \mathrm{hr}$ from $50^{\circ} \mathrm{C}$ to $420^{\circ} \mathrm{C}$. The debound parts were sintered at $1620^{\circ} \mathrm{C}$ in air for $2 \mathrm{hr}$. The relative density of the sintered specimen was $99 \%$ over.
\end{abstract}

\section{I 緒訔}

射出成形法は，七ラミックス粉末あるいは金属粉末の 成形法として注目を集めている。複雑形状を成形するの に優れていると言う特徵があるすのの，脱脂が難しいあ るいは長時間かかるなどの欠点がある。

前報では1，ステンレス粉末とポリエチレンーポりプ ロピレンーゴマ油系のバインダーを用いて, 有機溶媒に よるバインダー（特にゴマ油）の抽出脱脂を行らことに より脱脂時間を大幅に短縮出来ることを報告した。ここ ではアルミナ，ジルコニア粉末などの七ラミックス粉末 とポりエチレソーポリプロピレンーピーナッ油系のバイ ンダーを用いて射出成形を行い，その後アセトンによる 抽出脱脂を行った結果について報告する.$$
\text { II 実 験 方 法 }
$$

1 実験材料
アルミナ粉末は, Al160SG4 タイプ (昭和軽金属製, 平均粒子径 $0.5 \mu \mathrm{m}$, 比表面積 $5.5 \mathrm{~m}^{2} / \mathrm{g}$ ) を使用した。 たジルコニア粉末はHSY-3 タイプ(第一稀元素化学工業 製，平均粒子径 $0.8 \mu \mathrm{m}$ ，比表面積 $7.0 \mathrm{~m}^{2} / \mathrm{g}$ ) を使用した。 バインター類は，ポリェチレン (PE, スミカセン $\mathrm{G} 808$, 住友化学製),ポリプロピレン (PP, MA8108, 昭和電工製), ピーナッ油（精製品，試薬）を用いた。配合は Table 1

Table 1 The molding compositions. (vol\%)

\begin{tabular}{c|c|c|c|c}
\hline & $\mathrm{A}$ & $\mathrm{B}$ & $\mathrm{C}$ & $\mathrm{D}$ \\
\hline Ceramic powder & $\mathrm{Al}_{2} \mathrm{O}_{3}$ & $\mathrm{Al}_{2} \mathrm{O}_{3}$ & $\mathrm{Al}_{2} \mathrm{O}_{3}$ & $\mathrm{ZrO}_{2}$ \\
& 59.50 & 59.5 & 59.50 & 48.00 \\
\hline $\mathrm{PE}$ & 8.10 & 6.89 & 6.08 & 7.80 \\
\hline $\mathrm{PP}$ & 8.10 & 7.29 & 6.08 & 7.80 \\
\hline peanut oil & 24.3 & 26.32 & 28.34 & 36.4 \\
\hline
\end{tabular}

PE: polyethlene PP: polypropyrene 


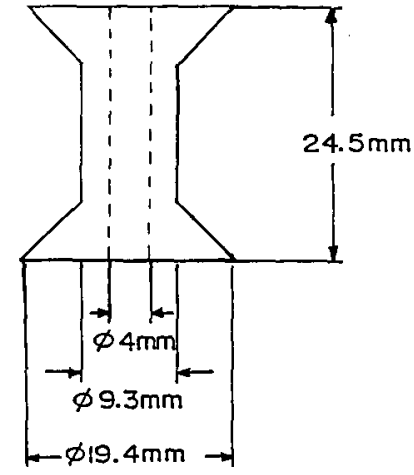

Fig. 1 Dimension of Sample.

に示す通りである。

\section{2 混練}

ラボプラストミル（東洋精機製）により，まず $180^{\circ} \mathrm{C}$ でポリエチレンとポリプロピレンを溶解した後粉末と ピーナッ油を添加して, 添加終了後は $140^{\circ} \mathrm{C}$ に混練を 温度を下げ30分間加熱混練した。涅練物は粉砕して成形 材料とした。

\section{3 成形}

タテ型プランジャ式射出成形機で, Fig. 1 に示すコマ 型 (表面積 $15.5 \mathrm{~cm}^{2}$ ，容積 $2.5 \mathrm{cc}$ ) を圧力 $660 \mathrm{~kg} / \mathrm{cm}^{2}$, 金 型温度 $27^{\circ} \mathrm{C}$ でノズル温度 $140 \sim 160^{\circ} \mathrm{C}$ の範囲で成形し た。

\section{4 抽出脱脂}

$500 \mathrm{cc}$ のビーカーにアセトンを $300 \mathrm{cc}$ 入れ，その中に コマ型の成形体を 10 個入れ $23^{\circ} \mathrm{C} て ゙ ， 0.5 \sim 24$ 時間放置 して抽出を行った.

\section{5 常圧脱脂}

抽出後の成形体を大穸中で常温から $50^{\circ} \mathrm{C}$ をで20分， さらに毎時 $100^{\circ} \mathrm{C}$ の昇温速度で $420^{\circ} \mathrm{C}$ まで昇温し， $420^{\circ} \mathrm{C}$ で 2 時間保持したのち，冷却した，合計脱脂時間 は約 4 時間である.

\section{6 焼結}

脱脂体をアルミナでは常温から $1620^{\circ} \mathrm{C}$ まで，ジルコ

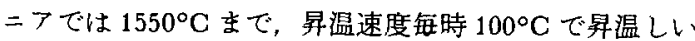
ずれの場合も同温度で 2 時間保持し, 毎時 $400^{\circ} \mathrm{C}$ の冷 却速度で冷却した.

\section{III結果と考察}

抽出を行ら場合ポリエチレンやポリプロピレンを溶解 しないで，ピーナツ油のみを抽出する有機溶媒として， トリクレン，テトラヒドロフラン，チルエーテルケト ン、トルエン，クロロホルム，フセトンなどが考えられ るが，環境問題や毒性等を考えて本研究ではつセトンを 使用した。 また予備実験の結果, 配合物中のピーナッ油 の体積率が20\%以上でないと抽出がうまく行かないこと
Table 2 The extraction ratio of peanut oil from the green parts with acetone solvent at $23^{\circ} \mathrm{C}$. (\%)

\begin{tabular}{c|c|c|c|c}
\hline $\mathrm{Hr}$ & A & B & C & D \\
\hline 0.5 & 22 & 25 & 29 & 33 \\
\hline 1 & 34 & 37 & 41 & 46 \\
\hline 2 & 43 & 51 & 59 & 60 \\
\hline 4 & 59 & 69 & 75 & 75 \\
\hline 6 & 70 & 78 & 80 & 83 \\
\hline 8 & 77 & 81 & 83 & 88 \\
\hline 16 & 83 & 87 & 90 & 89 \\
\hline 24 & 85 & 89 & 93 & 92 \\
\hline
\end{tabular}

Table 3 The relation between the extraction time and the ratio of non-defective unit. $(n=10)$

\begin{tabular}{c|c|c|c|c}
\hline $\mathrm{Hr}$ & A & B & C & D \\
\hline 0.5 & 0 & 0 & 0 & 0 \\
\hline 1 & 0 & 0 & 0 & 0 \\
\hline 2 & 0 & 0 & 0 & 0 \\
\hline 4 & 0 & 20 & 70 & 0 \\
\hline 6 & 0 & 100 & 70 & 80 \\
\hline 8 & 20 & 100 & 100 & 80 \\
\hline 16 & 20 & 100 & 100 & 100 \\
\hline 24 & 40 & 100 & 100 & 100 \\
\hline
\end{tabular}

から，Table 1 の配合を検討した。

成形時に，金型面にピーナッ油のにじみだしが見られ たので，スプルーやランナーや不良品の再生利用につい ては注意が必要であろら。

Table 2 に, 各配合での時間の释過にともならピーナ ッ油の抽出変化を示す。ポリエチレンやポリプロピレン 等のポリマーが少ないはど，ピーナツ油は抽出され易い、 が時間の経過とともに飽和状態になる.所定時間抽出後, 実験力法で述べた通常の 1 時間数 ${ }^{\circ} \mathrm{C}$ の年温速度と比較 乙て格段に早い㫒温速度で常圧脱脂を行い，その後烧結 操作を行った。

Table 3 に抽出時間と焼結体の良品率の関係を示すが， 良品とは表面クラックや変形もなく，焼結体相対密度が 99\%以上のものを示している.A 配合では100\%の条件 はなく，B 配合では 6 時間以上の抽出脱脂により $100 \%$ の良品率となる。また C 配合では8時間以上で，D配 合では16時間以上で100\%の良品率となる，このことは， 目安としてアルミナにおいては B，C配合ではピーナッ 油を88\%，すなわち全体のバインダ一類の55容積\%抽出 すれば高速脱脂が可能であると言える. ジルコニアでは ピーナッ油を $85 \%$ 以上，全体のバインダー類の60容量\% 抽出する必要がある。アルミナでは最適条件下 B 配合 
Table 4 The molding compositions. (vol\%)

\begin{tabular}{c|c}
\hline Alumina & 59.47 \\
\hline PE & 5.86 \\
\hline PP & 5.86 \\
\hline Wax & 2.34 \\
\hline AC & 4.69 \\
\hline penut oil & 21.79 \\
\hline
\end{tabular}

PE : polyethlene PP: polypropyrene Wax: carnauba wax AC: acryl-oligomer

では，抽出時間 6 時間，常王脱脂 4 時間合計 10 時間で脱 脂処理を行らことが出来る.これは従来の脱脂方法に比 較して，数分の1k短縮できることになる。このような 結果は，射出成形の改善や新しく工業化する場合に，多 いに参考になるるのと考えられる。

この配合系では成形体強度が低く取扱に注意が必要で ある.この問題を解決するために，カルナバワックスと アクリル系オリゴマー（分子量約1500）を添加して, Table 4 に示すような配合を検討した，成形時のピーナ
ツ油のにじみだしを防止することが出来るとともに，成 形体強度が王縮強度で約 3 倍になり, 成形体強度の改善 が認められる. 成形体をアセトン中で抽出脱脂したとこ ろ，82\%のピーナツ油を抽出していることが分かった。 その後㬰験方法で示した方法で, 常圧脱脂, 焼結を行っ たが100\%の良品率であり，相対密度も99\%以上であっ た.

\section{N 結 言}

アルミナとジルコニア粉末を用いて，ポリェチレンー ボリプロピレンーピーナツ油系のパインダーで射出成形 を行い，成形体をアセトン中で抽出脱脂を行った。その 結果フルミナではピーナツ油を $88 \%$ 以上，ジルコニアで は85\%以上抽出すれば，昇温速度 $100^{\circ} \mathrm{C}$ の高速脱脂が 可能であることが明らかとなった，また成形体強度は， カルナバワックスとアクリル系オリゴマーを添加するこ とで改良されることが明らかとなった。

$$
\text { 文献 }
$$

1）斎藤，金子：材料，39(1990), 844 ,

\section{新入正会員} (平成 3 年 7 月 9 日現在)

\begin{tabular}{|c|c|c|c|c|c|c|c|c|c|}
\hline 氏 & 名 & 卒業学校 & 卒業 & $\begin{array}{l}\text { 盒員 } \\
\end{array}$ & 門 & 務 & & 現 & 住 \\
\hline 冨 永 & 陽 一 & (在学中) & & 135041 & 粉末治金 & $\begin{array}{l}860 \text { 態本市黒髮2-39-1 熊本大学 } \\
\text { 大学院工学研究科 } 096-344-2111\end{array}$ & \multicolumn{3}{|c|}{ 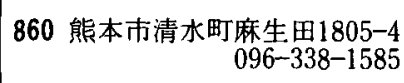 } \\
\hline 堀 尾 & 正 靱 & 大 & $46^{*}$ & 155024 & 化学工学 & $\begin{array}{r}184 \text { 小金并市中町2-24-16 東京 } \\
\text { 農工大学工学部物質生物工学科 } \\
0423-86-3303\end{array}$ & \multicolumn{3}{|c|}{ 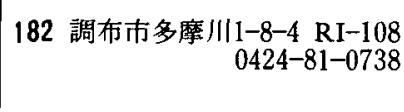 } \\
\hline 渡 辺 & 明男 & 大 & $53^{*}$ & 191036 & $\begin{array}{l}\text { セラミッ } \\
\text { クス }\end{array}$ & 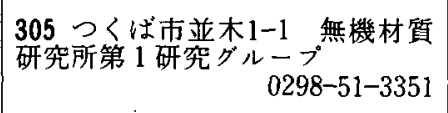 & \multicolumn{3}{|c|}{$\begin{array}{r}305 \text { つくば市竹園3-106-105 } \\
0298-55-0818\end{array}$} \\
\hline 四 方 & 良一 & 名工大 & 44 & 122072 & 無機材料 & $\begin{array}{r}597 \text { 貝塚市二色中町 太阪セメン } \\
\text { ト侏セラミックス部技術開発課 } \\
0724-31-8014\end{array}$ & \multicolumn{3}{|c|}{$\begin{array}{l}630 \text { 奈良市三条町606-76 奈良 } \\
\text { ハイタウン2-904 } 0742-22-7468\end{array}$} \\
\hline 山本 & 泰 次 & 京工瀻大 & 55 & 171111 & 無機材料 & $\begin{array}{r}597 \text { 貝塚市二色中町 大阪セメン } \\
\text { ト部技術開発課 } \\
0724-31-8014\end{array}$ & \multicolumn{3}{|c|}{$\begin{array}{r}573 \text { 枚方市岡南町5-18-15 } \\
0720-44-4095\end{array}$} \\
\hline
\end{tabular}

